\title{
Effect of Taxation on Dynamic Capital Structure Decisions of Quoted Industrial Firms in Nigeria
}

\author{
ORJINTA, HOPE IFEOMA \\ DEPARTMENT OF ACCOUNTANCY \\ FACULTY OF MANAGEMENT SCIENCES, \\ CHUKWUEMEK A ODUMEGWU OJUKWU UNIVERSITY \\ IGBARIAM CAMPUS, ANAMBRA STATE \\ EMAIL: IFYORJINTA@GMAIL.COM \\ PHONE NUMBER: 08060127990 \\ PROF. IFURUEZE, MESHACK S. \\ DEPARTMENT OF ACCOUNTANCY \\ FACULTY OF MANAGEMENT SCIENCES, \\ CHUKWUEMEK A ODUMEGWU OJUKWU UNIVERSITY \\ IGBARIAM CAMPUS, ANAMBRA STATE \\ DOI: $10.31364 / \mathrm{SCIRJ} / \mathrm{v} 6.18 .2018 . P 0818547$ \\ http://dx.doi.org/10.31364/SCIRJ/v6.i8.2018.P0818547
}

\begin{abstract}
The study investigated the effect of taxation on dynamic capital structure financing decisions of quoted industrial firms in Nigeria, using panel data collected from the annual report of the above mentioned companies within the period of fifteen years spanning 2003-2017. The study used longitudinal and ex-post facto research design. The sampled data was analyzed using simple regression tools. The study decomposed the different tax components into individual tax level and corporate tax level. The analysis of the result showed a significant positive relationship between company income tax and capital structure financing using dynamic model approach. The result revealed positive significant relationship between interest tax, tax shield and the companies' equity ratio. In principle, the results support the view that capital structure financing choices are significantly affected by taxation both at individual and corporate level. Based on the result of the analysis and its findings, the study recommends among others that in making capital structure financing decisions, firms should consider the effect of taxes at both the individual level and company's level. Industrial firms should also optimize the mix of debt financing in order to enjoy the associated benefits in terms of increase in tax shield.
\end{abstract}

Keyword: Equity/debt financing, interest tax, company tax, tax shield and dividend tax

\section{INTRODUCTION}

One of the most important imperfections is the presence of taxes. The relation between capital structure and taxes has been the subject of extensive theoretical analysis. When taxes are very much applicable to corporate income, debt financing becomes advantageous. Pratheepan and Banda (2016) argued that the mix of debt and equity (the decision of capital structure) is one of the most essential financial policy level decisions. In the corporate form of business, generally it is the task of the top management to take capital structure decisions in a way that it will increase the firm value. Though, maximization of firm value is not an easy task since it involves the selection of debt and equity securities in a balanced proportion keeping in view of different various costs and benefits connected with these securities.

Firms can finance its investments using equity, debt or both. Using equity financing connotes sourcing of fund by issuing stock, primarily common stock. A firm sourced debt by borrowing from its shareholders, from financial institutions or from the public. When drawing line of comparison between debt and equity financing, borrowing is more advantageous to public companies because the cost of debt which is interest payment is tax deductible while the cost of equity which is dividend is not tax deductible. Devereux, Maffini and Jing Xing (2015) opined that corporation taxes typically permit the deduction of interest payments but not the opportunity cost of equity finance and as such create an opportunity to using debt rather than equity finance. Interest payments can generally be deducted from taxable profits while such a deduction is not available in the case of equity financing. Corporations do not only use external capital but also intercompany loans in order to optimize their capital structure. Devereux, Maffini and Jing Xing (2015) opined that corporation taxes typically permit the deduction of interest payments but not the opportunity cost of equity finance 
and as such create an opportunity to using debt rather than equity finance. Overesch and Voeller (2008) argued that capital structure adjustments can be used to reduce the total tax burden on company investment since the taxation of the return on equity and debt capital differs in most countries.

Capital financing decision poses a lot of challenges to firms. A wrong financing decision has the capability of stalling the fortunes of any business adventure. However, few studies that have been done on capital structure using tax as a variable were done using the banking sector and selected non-financial companies, these studies include; Orjinta and Agubata (2017), Ogbulu and Emeni (2012), Ogebe, Patric and Alewi, (2013). The findings from these studies differs on the degree of the effect of tax on capital structure decision, for instance Orjinta and Agubata (2017), Ogebe, Patric and Alewi, (2013) finds positive effect of tax on capital structure decision, Ogbulu and Emeni (2012), finds no impact while the study of Salawu (2007) shows a negative effect of tax on capital structure decision. The findings from these studies are inconclusive and therefore difficult to draw policy implication from. Little is known of studies that have been carried out to ascertain the effects of corporate profit tax and personal income tax on capital structure decision using both equity and debt model. Moreover, studies on the effects of various taxes and capital structure have produced mixed results. The results of empirical literature are contradictory which justifies further research. The Nigerian capital market is relatively under developed and therefore the traditional capital structure theories that have their origin in the developed countries needed to be tested in the Nigerian context. It is against this background that this study was carried out. Thus, this is the gap this study seeks to fill. Therefore, this paper aims at analyzing the effects of taxation on capital structure financing decisions using a dynamic modeling of Nigeria industrial companies while taking into account both personal and corporate income taxation. To investigate the effect of taxation on capital structure, we introduced interest income deduction, dividend tax, company income tax, debt tax shield and profit in Nigeria.

This paper is partitioned into five sections including this introduction. Section two dwells on conceptual framework and review of related literature, section three dealt on methodology while in section four we discussed our hypothesized results and our findings. Finally we drew conclusion on section five and made our recommendations for policy implications.

\section{Framework}

\section{1: $\quad$ Theoretical Literature}

This study was anchored on Static Trade-off Theory. The static trade-off theory supports that firms have optimal capital structures which they determine by trading off the costs against the benefits of the using debt or equity. One of the benefits of using debt is the advantage of a debt tax shield. The static trade-off theory explains that the tax advantage of debt and several leverage-related costs is related to the trade-off in a firm's decision to get optimal capital structure. The firms have to set a target debt-equity ratio that maximized firm value by minimizing the costs of prevailing market imperfections (taxes, bankruptcy costs, agency costs).The static trade-off assumes that the firms with a greater risk of experiencing financial distress tend to borrow less than firms having lower financial distress risk. One important prediction of the static trade-off theory is that firms target their capital structures; i.e. if the actual leverage ratio deviates from the optimal one, the firm will adapt its financing behavior in a way that brings the leverage ratio back to the optimal level. The theory says that every firm has an optimal-equity ratio that maximizes its value. The theory affirms that firms have optimal capital structure which they determine by trading-off the costs against the benefits of the use of debt and equity. The benefits from debt tax shield are thus adjusted against cost of financial distress.

\section{2: $\quad$ Empirical Literature}

Interest Tax and Dynamic Capital Structure Decisions

Orjinta and Agubata (2017) discovered a positive relationship between interest tax deduction and debt financing. Graham and Harvey (2001) interview 392 CFOs in the U.S. and find that the tax advantage of interest deductibility is of significant concern by CFOs in large, regulated, and dividend-paying firms. In contrast, Auclert and Struyven (2012) argue empirically that the Notional Interest Deduction had an insignificant effect on capital structure due to a secular reduction in leverage experienced by Belgian firms since 2001. Panier, Perez-Gonzalez and Villanueva (2012) found that the notional interest deduction led to a significant increase in the share of equity in the capital structure and that both incumbent and new firms increase their equity ratios after the introduction of the notional interest deduction. Again, the largest responses to these changing tax incentives are found among large and new firms.

\section{Dividend Tax and Capital Structure Decisions}

Several papers have found a negative relationship between dividend tax and debt. This negative relationship is plausible due to the extent that debts and dividends are substitutes employed by managers to mitigate agency conflicts or asymmetric information problems. This implies that an increased market debt to capital ratio reduces dividend payout rates and vice versa (Hassan et al; 2013). Higher dividend payment causes individual to pay high personal tax. Hassan et al. (2013) proposed that due to the impediment in 
personal tax advantage of dividend, the shareholder greatly prefers to invest in real assets to use internal financing as compared to external financing. Moreover empirical evidence with respect to the possible impact of dividend tax on capital structure decision is still rare. However, studies considering these aspects find significant effects of dividend tax. For example, Givoly et al. (1992) find a negative impact of cross-sectional differences in dividend yields on changes in leverage. They interpret this result as an indirect indicator for the impact of personal taxation. Graham (2000) analyses the effect of withholding tax using cross-sectional differences in companies' payout ratios in order to estimate the variation in dividend income tax. He provides evidence that discrimination of interest payments at the dividend income tax level alleviates corporate leverage. Following a similar approach, Alworth and Arachi (2001) find cross-sectional as well as time-series effects of dividend income taxation for a sample of Italian companies. Therefore, in order to increase the firm value and maintain optimal capital structure, firms have to maintain low dividend and low debt. It implies that firms reduce interest payment and taxable dividend without reducing the return on capital (Sanusi and Taha; 2015). The best strategies of tax deduction and the maximization of a firm's value are: issue more debt and maintain small dividend payments. However, the empirical evidence produced by Fama and French (1998) proves that the positive and negative relationships exist between the dividend and a firm's value; and between dividend and taxes, respectively. The reduction in dividend payment increases the personal tax penalty and decreases the net tax benefit. Liu, Zhang and Gao (2015) found that the effect of dividend tax on capital structure is more pronounced in large dividend payout firms. They also show that the effect of dividend tax on debt varies among the different forms of debt financing.

\section{3: $\quad$ Empirical Studies}

Orjinta and Agubata (2017) examined the effect of taxation on capital structure decisions in Nigeria, using pool data collected from 45 non-financial companies within the period of 10years (2007-2016) using ex-post facto research design. Their finding provides strong support for the trade-off theory of capital structure They recorded a positive relationship between taxes and capital structure proxy by debt ratio.

Karasahin and Kucuksarac (2016) in their Turkey study found that firm-specific factor have similar effects on both book and market leverage ratios except the effect of growth opportunity and that the size of a firm is positively associated with its leverage ratio, particularly with long-term leverage ratio. Tangibility is negatively related to the short-term leverage ratio whereas it is positively related to the long-term leverage ratio while profitability and liquidity have negative effects on leverage, particularly on short-term leverage ratio. There seems to be positive association between inflation and leverage. On the other hand, firm leverage and economic growth are negatively related.

Capital structures of Iranian firms were completely explained by pecking order theory of capital structure in a study done by Abbasi and Delghandi (2016) for the period of 10years from 2005 to 2014. Their finding shows that profitability is the most important determinant of capital structure followed by tangibility, growth and business risk. They also proved that profitability and business risk are inversely correlated with debt ratio while liquidity and growth are directly associated to debt ratio.

Akman, Gokbulut, Temel Nalin and Gokbulut (2015) investigated the firm -specific determinants of capital structure under changing economic conditions in Turkey over the period of 2003 to 2011. The result show that established theories such as trade-off, pecking order and market timing fail to explain the observed leverage adequately.

Devereux, Maffini and Xing (2015) examined how company's capital structure is affected by the corporate income tax system, using a dynamic adjustment model of capital structure. They found a positive and substantial long-run tax effect on companies' financial leverage. They also found that companies adjust their capital structures gradually in response to changes in the marginal tax rate.

A study based on Chinese capital market done by Chen Deng (2015) between the period of 2010 to 2014 found that a company with higher tax rate basically obtain lower cash flow from operating activities while they also found that relationship between total debtasset ratio and profitability is negative while that of long-term debt and profitability is positive.

In a Malaysian study done by Sanusi and Taha (2015) on the effect of corporate tax to the firm's capital structure. They exploit a time series and cross sectional data of 35 companies over 2007-2012 and found that tax deduction reduces the current liability item relative to the firms that prefer equity financing while the lower debt portion is reported for the firm with high profitability. Their results also showed that, the significant of corporate tax is consistent with the theory that firms are subjected to lower corporate tax rates which would lead them to employ more debt in their capital structures

www.scirj.org

(C) 2018, Scientific Research Journal

http://dx.doi.org/10.31364/SCIRJ/v6.i8.2018.P0818547 
Hassan et al. (2013) examined tax shield and its impact on corporate dividend policy with evidence from Pakistani stock market using a sample panel data of 33 companies listed at Karachi Stock Exchange for the period of 6years from 2005 to 2010. They found that the firm size and profitability are positively related to the dividend payout policy while there is insignificant relationship between tax shield and leverage on the dividend payout policy.

A Jordan study by Al-Shubiri (2011) provided new insights into the way in which the capital structure and market power and capital structure and profitability are related. She used sample data of fourteen banks listed on the Amman Stock Exchange for the period from 2005 to 2008.The ols estimation results indicate that, at lower and higher ranges of Tobin's $Q$, banks employ higher debt, and reduce their debt at intermediate range. She also found that size tangibility variables have a positive influence both on capital structure and on the other hand on growth, while risk and ownership variables have a negative influence on capital structure.

Buettner, Overesch, Schreiber and Wamser (2006) analysed the impact of taxes and lending conditions on the financial structure of German multinationals in the period from 1996 to 2003. The results support a significant impact of local taxes as well as local credit market conditions on financing decision and indicate significant adverse revenue effects from the adjustment of the capital structure.

Mintz and Weichenrieder (2005) examined taxation and the financial structure of German outbound and obtain mixed results, where the tax rate only affects debt while external debt is not related to local lending conditions.

Table 2.3 Webometric Analysis of Selected Empirical Works On Taxation and Dynamic capital structure decisions

\begin{tabular}{|c|c|c|c|c|c|c|}
\hline Name & Year & Country & Period & Title & Variables & Findings \\
\hline $\begin{array}{l}\text { 1) Orjinta } \\
\text { and } \\
\text { Agubata }\end{array}$ & 2017 & Nigeria & $\begin{array}{l}2007 \text { to } \\
2016\end{array}$ & $\begin{array}{ll}\text { Effect of taxes on } \\
\text { capital } & \text { structure } \\
\text { decisions } & \end{array}$ & $\begin{array}{l}\text { Interest tax, Tax } \\
\text { shield, Dividend } \\
\text { tax, Company } \\
\text { income tax, debt } \\
\text { ratio. }\end{array}$ & $\begin{array}{l}\text { Their finding provides strong support for the } \\
\text { trade-off theory of capital structure and they } \\
\text { recorded a positive relationship between taxes } \\
\text { and capital structure proxied by debt ratio. }\end{array}$ \\
\hline $\begin{array}{l}\text { 2) } \\
\text { Abbasi and } \\
\text { Delghandi }\end{array}$ & 2016 & Iran & $\begin{array}{l}2005 \text { to } \\
2014\end{array}$ & $\begin{array}{l}\text { Impact of firm } \\
\text { specific factors on } \\
\text { capital structure } \\
\text { based-An empirical } \\
\text { study of the } \\
\text { Tehran's stock } \\
\text { market companies. }\end{array}$ & $\begin{array}{l}\text { Tangibility, } \\
\text { profitability, } \\
\text { growth, risk }\end{array}$ & $\begin{array}{l}\text { They found that profitability and business risk } \\
\text { are inversely correlated with debt ratio while } \\
\text { liquidity and growth are directly associated } \\
\text { with debt ratio. Their results were in line with } \\
\text { pecking order theory. }\end{array}$ \\
\hline $\begin{array}{l}\text { 3) } \\
\text { Sorana } \\
\text { Vatavu }\end{array}$ & 2015 & Rome & $\begin{array}{l}2003 \\
\text { to } 2010\end{array}$ & $\begin{array}{l}\text { The impact of } \\
\text { capital structure on } \\
\text { financial } \\
\text { performance in } \\
\text { Romanian listed } \\
\text { companies }\end{array}$ & $\begin{array}{ll}\text { Short-term } & \text { debt, } \\
\text { long } & \text { term } \\
\text { debt,total } & \\
\text { debt,total equity, } \\
\text { ROA, ROE. }\end{array}$ & $\begin{array}{l}\text { Results of her findings indicate that } \\
\text { performance in Romanian companies is higher } \\
\text { especially when they avoid debt and operate } \\
\text { based on equity. }\end{array}$ \\
\hline $\begin{array}{l}\text { 4) } \\
\text { Cheng } \\
\text { Deng }\end{array}$ & 2015 & China & $\begin{array}{l}2010 \\
\text { To } 2014\end{array}$ & $\begin{array}{lr}\text { Impact } & \text { of } \\
\text { corporate } & \text { income } \\
\text { tax on the } & \text { capital } \\
\text { structure } & \text { of } \\
\text { Canadian } & \text { listed } \\
\text { companies } & \end{array}$ & $\begin{array}{l}\text { Interest, } \\
\text { profitability, } \\
\text { long term debt, } \\
\text { asset ratio. }\end{array}$ & $\begin{array}{l}\text { The result of her findings showed that the } \\
\text { relationship between total debt-asset ratio and } \\
\text { profitability is negative while relationship } \\
\text { between long-term debt to total debt ratio and } \\
\text { profitability is positive. }\end{array}$ \\
\hline $\begin{array}{l}\text { 5) } \\
\text { Arsov, S. } \\
\text { and }\end{array}$ & 2016 & $\begin{array}{l}\text { Balkan } \\
\text { countries }\end{array}$ & $\begin{array}{l}2008 \text { to } \\
2013\end{array}$ & $\begin{array}{l}\text { Determinants of } \\
\text { capital structure: } \\
\text { An empirical study }\end{array}$ & $\begin{array}{l}\text { profitability, } \\
\text { tangibility, size, } \\
\text { growth, tax }\end{array}$ & $\begin{array}{l}\text { Their result showed that larger companies and } \\
\text { those with higher fixed asset investments } \\
\text { exhibit higher leverage while the more }\end{array}$ \\
\hline
\end{tabular}




\begin{tabular}{|c|c|c|c|c|c|c|}
\hline Naumoski & & & & $\begin{array}{l}\text { of companies from } \\
\text { selected post- } \\
\text { transition } \\
\text { economies }\end{array}$ & $\begin{array}{ll}\text { shields, } & \text { risk, } \\
\text { ownership } & \end{array}$ & $\begin{array}{l}\text { profitable companies have not been found } \\
\text { statistically significant. }\end{array}$ \\
\hline $\begin{array}{l}\text { 6) } \\
\text { Liang }\end{array}$ & 2016 & China & $\begin{array}{l}2008 \\
\text { to } 2015\end{array}$ & $\begin{array}{l}\text { The recognition of } \\
\text { capital structure } \\
\text { peer effect of } \\
\text { Chinese listed } \\
\text { companies. }\end{array}$ & $\begin{array}{l}\text { Equity stock, } \\
\text { company size, } \\
\text { market value } \\
\text { leverage, } \\
\text { profitability, } \\
\text { asset tangibility, } \\
\text { non-debt tax } \\
\text { shields, }\end{array}$ & $\begin{array}{l}\text { The result of their finding showed that capital } \\
\text { structure of listed companies in China is not } \\
\text { independently decided by the company } \\
\text { managers but in the process of decision- } \\
\text { making, the capital structure of peer firms is } \\
\text { considered as the important reference factor. }\end{array}$ \\
\hline $\begin{array}{l}\text { 7) } \\
\text { Karasahin, } \\
\text { Ramazan } \\
\text { and } \\
\text { Kukuksara } \\
\text { c }\end{array}$ & 2016 & $\begin{array}{l}\text { Turkey } \\
\text { Borsa } \\
\text { Istanbul }\end{array}$ & $\begin{array}{l}2007 \text { to } \\
2008\end{array}$ & $\begin{array}{l}\text { Revisiting capital } \\
\text { structure of non- } \\
\text { financial public } \\
\text { firms in Turkey }\end{array}$ & $\begin{array}{l}\text { Size, } \\
\text { profitability, } \\
\text { tangibility; } \\
\text { liquidity, firm } \\
\text { leverage, } \\
\text { economic } \\
\text { growth. }\end{array}$ & $\begin{array}{l}\text { They found that size is positively associated } \\
\text { with its leverage ratio while tangibility, } \\
\text { profitability and liquidity have negative effects } \\
\text { on short-term leverage ratio. }\end{array}$ \\
\hline $\begin{array}{l}\text { 8) } \\
\text { Perpur, } \\
\text { Curak and } \\
\text { Poposki }\end{array}$ & 2016 & Croatia & $\begin{array}{l}2001 \text { to } \\
2010\end{array}$ & $\begin{array}{l}\text { Corporate capital } \\
\text { structure; The case } \\
\text { of large Croatian } \\
\text { companies. }\end{array}$ & $\begin{array}{l}\text { Internal firm- } \\
\text { specific } \\
\text { characteristics } \\
\text { such as Size, } \\
\text { profitability, } \\
\text { liquidity }\end{array}$ & $\begin{array}{l}\text { The result of their findings revealed that } \\
\text { neither of the two computed theories } \\
\text { exclusively and completely explain the } \\
\text { financing behavior of the analysed companies. }\end{array}$ \\
\hline $\begin{array}{l}\text { 9) } \\
\text { Akman et } \\
\text { al }\end{array}$ & 2015 & Turkey & $\begin{array}{l}2003 \text { to } \\
2011\end{array}$ & $\begin{array}{l}\text { Capital structure in } \\
\text { an emerging stock } \\
\text { market: The case } \\
\text { of Turkey. }\end{array}$ & $\begin{array}{l}\text { Taxes, non-debt } \\
\text { tax shield, asset } \\
\text { structure, } \\
\text { profitability, } \\
\text { business risk, } \\
\text { liquidity }\end{array}$ & $\begin{array}{l}\text { The result of panel data fixed effect model } \\
\text { show that market timing and growth } \\
\text { opportunities have positive effect on capital } \\
\text { structure; profitability, asset structure, liquidity } \\
\text { and asset utilization have negative effect while } \\
\text { company size, taxes, non-debt tax shield and } \\
\text { business risk have no significant relationship } \\
\text { with leverage. }\end{array}$ \\
\hline $\begin{array}{l}\text { 10) } \\
\text { Hassan, } \\
\text { Tanveer,Si } \\
\text { ddique and } \\
\text { Mudasar }\end{array}$ & 2013 & Pakistan & $\begin{array}{l}2005 \text { to } \\
2010\end{array}$ & $\begin{array}{l}\text { Tax shield and its } \\
\text { impact on } \\
\text { corporate dividend } \\
\text { policy; Evidence } \\
\text { from Pakistan } \\
\text { Stock market. }\end{array}$ & $\begin{array}{l}\text { Leverage } \\
\text { profitability, } \\
\text { size, tax shield }\end{array}$ & $\begin{array}{l}\text { Their results showed a significant positive } \\
\text { relationship between profitability, size and } \\
\text { dividend policy. They also showed the } \\
\text { insignificant relationship between the tax } \\
\text { shield and leverage on the dividend payout } \\
\text { ratio. }\end{array}$ \\
\hline $\begin{array}{l}11) \\
\text { Hemmelga } \\
\mathrm{m} \text { and } \\
\text { Teichmann }\end{array}$ & 2013 & Europe & $\begin{array}{l}1997 \text { to } \\
2011\end{array}$ & $\begin{array}{lr}\text { Tax } & \text { reforms and } \\
\text { the } & \text { capital } \\
\text { structure of banks }\end{array}$ & $\begin{array}{l}\text { CIT, tax rate, } \\
\text { debt tax shield, } \\
\text { pretax, } \\
\text { ROA,total } \\
\text { assets, size, } \\
\text { leverage ratio. }\end{array}$ & $\begin{array}{l}\text { Their result suggest that taxation influences } \\
\text { leverage, CIT rate and the value of debt tax } \\
\text { shield }\end{array}$ \\
\hline $\begin{array}{l}\text { 12) } \\
\text { Modugu }\end{array}$ & 2013 & ---- & ---- & $\begin{array}{lr}\text { Capital } & \text { structure } \\
\text { decision; } & \text { An } \\
\text { overview } & \end{array}$ & $\begin{array}{l}\text { Debt, equity, } \\
\text { profitability, } \\
\text { size,risk } \\
\text { Liquidity, }\end{array}$ & $\begin{array}{l}\text { They found that financing a company solely } \\
\text { with equity or debt may not be an optimal } \\
\text { capital decision. }\end{array}$ \\
\hline $\begin{array}{l}\text { 13) } \\
\text { Andrew }\end{array}$ & 2012 & USA & $\begin{array}{l}1998 \text { to } \\
2010\end{array}$ & $\begin{array}{lr}\text { How do } & \text { taxes } \\
\text { affect } & \text { capital } \\
\text { structure } & \\
\text { Stron }\end{array}$ & $\begin{array}{l}\text { Marginal tax } \\
\text { rate, pre-tax, cost } \\
\text { of debt }\end{array}$ & $\begin{array}{l}\text { He found effect of taxes on firms' overall } \\
\text { usage to be insignificant i.e. rather than } \\
\text { influencing the total debt in firm's capital }\end{array}$ \\
\hline
\end{tabular}




\begin{tabular}{|c|c|c|c|c|c|c|}
\hline & & & & & & $\begin{array}{l}\text { structure; taxes affect the relative composition } \\
\text { of debt. }\end{array}$ \\
\hline $\begin{array}{l}\text { 14) } \\
\text { Sanusi and } \\
\text { Taha }\end{array}$ & 2015 & malaysia & $\begin{array}{l}2007 \text { to } \\
2012\end{array}$ & $\begin{array}{l}\text { An empirical } \\
\text { analysis of capital } \\
\text { structure decisions } \\
\text { in Malaysian listed } \\
\text { companies }\end{array}$ & $\begin{array}{l}\text { Tax size, } \\
\text { bankruptcy cost, } \\
\text { profitability, } \\
\text { tangibility }\end{array}$ & $\begin{array}{l}\text { The result of their findings showed that } \\
\text { corporate tax is significant and consistent with } \\
\text { the theory that the firms are subjected to lower } \\
\text { corporate tax rates which would lead them to } \\
\text { employ more debt in their capital structure. } \\
\text { The results also revealed that tax deduction } \\
\text { reduces the current liability item relative to the } \\
\text { firms that prefer equity financing. }\end{array}$ \\
\hline $\begin{array}{l}\text { 15) } \\
\text { Teraoui et } \\
\text { al }\end{array}$ & 2012 & Tunisia & & $\begin{array}{lr}\text { Taxation } & \text { and } \\
\text { capital } & \text { structure } \\
\text { choice: } & \text { Survey } \\
\text { evidence } & \end{array}$ & $\begin{array}{l}\text { Taxation, non- } \\
\text { debt tax shields }\end{array}$ & $\begin{array}{l}\text { Their results reflect the importance of interest } \\
\text { deductibility in which is an advantage that } \\
\text { encourages leaders to use debt as a major } \\
\text { source of financing. They also show the } \\
\text { importance of non-debt tax shields on the } \\
\text { capital structure choice. }\end{array}$ \\
\hline $\begin{array}{l}\text { 16) } \\
\text { Al-shubiri } \\
\text { Faris Nasif }\end{array}$ & 2011 & Jordan & $\begin{array}{l}2005 \text { to } \\
2008\end{array}$ & $\begin{array}{l}\text { Capital structure } \\
\text { and market power; } \\
\text { Evidence from } \\
\text { Jordanian banks. }\end{array}$ & $\begin{array}{l}\text { Total assets, } \\
\text { total debt, Tobin } \\
\text { Q growth, } \\
\text { profitability, } \\
\text { size, ownership, } \\
\text { risk, tangibility } \\
\text { ratio }\end{array}$ & $\begin{array}{l}\text { Their OLS estimation results indicate that at } \\
\text { lower and higher ranges of Tobin's Q, banks } \\
\text { employ higher debt and reduce their debt at } \\
\text { intermediate range. He also found that size, } \\
\text { tangibility variables have a positive influence } \\
\text { on both capital structure and growth while risk } \\
\text { and ownership variables have a negative } \\
\text { influence on capital structure. }\end{array}$ \\
\hline $\begin{array}{l}\text { 17) } \\
\text { Devereux } \\
\text { et al }\end{array}$ & 2015 & UK & $\begin{array}{l}2001 \text { to } \\
2010\end{array}$ & $\begin{array}{l}\text { Corporate } \\
\text { incentive and } \\
\text { capital structure: } \\
\text { Empirical evidence } \\
\text { from UK tax } \\
\text { returns }\end{array}$ & $\begin{array}{l}\text { Leverage, } \\
\text { marginal tax } \\
\text { rate, average } \\
\text { effective tax } \\
\text { rate, } \\
\text { profitability, } \\
\text { tangibility }\end{array}$ & $\begin{array}{l}\text { Using a dynamic capital structure model, they } \\
\text { found a large and positive long-run effect of } \\
\text { taxation on companies' leverage ratio. }\end{array}$ \\
\hline $\begin{array}{l}\text { 19) } \\
\text { Overesch } \\
\text { and Voetter } \\
\text { Dermis }\end{array}$ & 2008 & Europe & $\begin{array}{l}2000 \text { to } \\
2005\end{array}$ & $\begin{array}{l}\text { The impact of } \\
\text { personal and } \\
\text { corporate taxation } \\
\text { on capital structure } \\
\text { choices. }\end{array}$ & $\begin{array}{l}\text { Debt to assets } \\
\text { ratio, loss carry } \\
\text { forward, } \\
\text { tangibility, total } \\
\text { assets }\end{array}$ & $\begin{array}{l}\text { They found a positive association between } \\
\text { changes in leverage and changes in corporate } \\
\text { tax rates. Their findings supported the tax - } \\
\text { based theories of capital structure. }\end{array}$ \\
\hline $\begin{array}{l}\text { 20) } \\
\text { Buettner et } \\
\text { al }\end{array}$ & 2006 & Germany & $\begin{array}{l}1996 \text { to } \\
2003\end{array}$ & $\begin{array}{l}\text { Taxation and the } \\
\text { choice of capital } \\
\text { structure: Evidence } \\
\text { from a panel of } \\
\text { German } \\
\text { multinationals }\end{array}$ & $\begin{array}{l}\text { Debt, profit, } \\
\text { external debt, } \\
\text { intercompany } \\
\text { loans, tax rate }\end{array}$ & $\begin{array}{l}\text { Their results clearly confirm a positive impact } \\
\text { of taxes and an adverse effect of local lending } \\
\text { conditions on the leverage. }\end{array}$ \\
\hline
\end{tabular}

\section{METHODOLOGY}


3.1: $\quad$ Research Design. The study adopted ex-post facto research design and used a panel data which consisted of time series and longitudinal data collected from the published financial statement of 15 quoted industrial companies for the period of 15 years spanning 2003 to 2017. The firms were selected using stratified random sampling techniques based on the availability of data.

\subsection{Data Analysis Method}

In analyzing the data, the study used multiple regressions to identify the possible effects of tax (corporate and individual tax) on both equity and debt financing of selected quoted industrial companies in Nigeria. The selected industrial companies are as follows: Academy Press, A.G Leventis, Ashaka Cement, Austin Laz \& Co., Beta Glass Co., Cement Co. Of Northern Nigeria(CCNN), Costain West Africa, Cutix Co., Dangote Cement, Julius Berger Nigeria, John Holt, Nigerian Ropes, Red Star Express, Roads Nigeria and Greif Nigeria. The study conducted some preliminary analysis such as descriptive statistics and correlation matrix. The panel regression analysis was aided by E-view software version 9.5

\section{3: $\quad$ Data and Variables Description}

The study used effective tax on interest, dividend, company income tax and tax shield as (independent variables) while equity was used as dependent variable; profit was used as control variable.

Operationalization of variables:

\begin{tabular}{|l|l|}
\hline Variables & Measures/Proxy \\
\hline Debt ratio (DEBR) & Debt /Total Asset \\
\hline Equity ratio (EQR) & Equity/ Total Asset \\
\hline Effective tax on interest income (INTAX) & Tax on interest income /debt \\
\hline Effective tax on dividend income (DIVTAX) & Tax on interest dividend /equity (with-holding tax) \\
\hline Company income tax (CIT) & CIT/Operating expenses \\
\hline Debt Tax Shield (TAS) & Debt Tax Shield / Profit before interest and tax \\
\hline Profit before interest and tax (PBIT) & PBIT/ Total asset. (Control variable) \\
\hline
\end{tabular}

\section{Model Specification}

The linear regression model was designed to test each of the null hypotheses. The model used was adopted from the work of Hemmelgam and Teichmann (2013) and Panier et al (2015) which was modified to suite the variables used in this study.

DEBR $_{\mathrm{it}}=\delta_{0}+\delta_{1} \mathrm{INTAX}_{\mathrm{it}}+\delta_{2}$ DIVTAX $_{\mathrm{it}}+\delta_{3} \mathrm{CIT}_{\mathrm{it}}+\delta_{4} \mathrm{TAS}_{\mathrm{it}}+\delta_{\mathbf{5}} \mathrm{PBIT}_{\mathrm{it}}+\varepsilon_{\mathrm{it}}$

$\mathrm{EQR}_{\mathbf{i t}}=\delta_{0}+\delta_{1} \mathrm{INTAX}_{\mathrm{it}}+\delta_{2}$ DIVTAX $_{\mathrm{it}}+\delta_{3} \mathrm{CIT}_{\mathrm{it}}+\delta_{\mathbf{4}} \mathrm{TAS}_{\mathrm{it}}+\delta_{\mathbf{5}} \mathrm{PBIT}_{\mathrm{it}}+\varepsilon_{\mathrm{it}} \quad-\quad--2$

$\mathrm{d}_{0}=$ Constant; $\mathrm{d}_{1} \ldots \mathrm{d}_{5}=$ are the coefficient of the regression equation;

$\varepsilon=$ stochastic error term of firm $i$ at time $t$ capturing other unexplained variable; $i=$ is the firm cross-sectional error component and $\mathrm{t}=$ time series.

\section{DATA ANALYSIS}

In analyzing the data, the study used multiple regressions to identify the possible effects of tax (corporate and individual tax) on capital structure of quoted industrial firms in Nigeria. The study conducted some preliminary analysis such as descriptive statistics and correction matrix.

Table 4.1: Summary of the descriptive statistics of the sampled firms.

\begin{tabular}{|l|l|l|l|l|l|}
\hline Variables & Mean & Max & Min & Std. Dev. & JB $($ P-value $)$ \\
\hline DEBR & 6.6367 & 13.0000 & 2.0000 & 3.2939 & $0.0000^{*}$ \\
\hline EQR & 5.4050 & 5.8040 & 5.0830 & 4.7384 & $0.0309^{* *}$ \\
\hline DIVTAX & 12.0940 & 2.4133 & 0.7345 & 1.5653 & $0.0434^{* *}$ \\
\hline INTAX & 1.1007 & 1.9700 & 0.1244 & 0.9896 & $0.0057^{*}$ \\
\hline CIT & 6.5000 & 5.5882 & 5.3794 & 5.8155 & $0.0034^{*}$ \\
\hline TAS & 5.6223 & 6.0343 & 1.3190 & 2.2271 & $0.0395^{* *}$ \\
\hline PBIT & 5.8318 & 6.2353 & 5.5323 & 02110 & $0.0782^{* * *}$ \\
\hline
\end{tabular}

Source: Author's summary of descriptive statistics computation using Eviews8.5 
Note: $* 1 \%, * * 5 \%$ and $* * * 10 \%$ level of significance.

Table: 4.1 Shows the mean (average) for each of the variables their maximum, minimum, standard deviation and Jarque-Bera (JB) statistics (Normality test). The result provided some insight into the nature of the data from the quoted firm used for the study. Firstly, the large difference between the maximum and minimum values of debt ratio shows that the sampled firms in the study are not dominated by either highly geared or low geared companies. The small difference between the maximum and minimum value of equity finance ratio indicates most of the sampled firms used similar or close equity finance ratio.

Lastly, in table 4.1, the Jarque-Bera (JB.) which test for normality or existence of outliers or extreme value among the variables shows that all the variable are normally distributed at $1 \%, 5 \%$ and $10 \%$ level of significance. Debt ratio, interest tax and company income tax except were significant at $1 \%$; equity ratio, dividend tax and tax shield were significant at $5 \%$ while profit before interest and tax is significant at $10 \%$. This means that any variables with outlier are not likely to distort the conclusion and are therefore reliable for drawing generalization. This also justify the use of ordinary least square estimation techniques.

\section{Table 2: Person Correlation Matrices}

The Pearson correlation metrics shows the extent to which the variables move together with each other over time within the study

\begin{tabular}{|l|l|l|l|l|l|l|l|}
\hline & DEBR & EQR & INTAX & DIVTAX & CIT & TAS & PBIT \\
\hline DEBR & 1.0000 & & & & & & \\
\hline EQR & 0.5877 & 1.0000 & & & & & \\
\hline INTAX & 0.4853 & 0.3459 & 1.0000 & & & & \\
\hline DIVTAX & 0.1627 & 0.2487 & -0.0052 & 1.0000 & & & \\
\hline CIT & 0.1568 & 0.0807 & 0.2122 & -0.2493 & 1.0000 & & \\
\hline TAS & 0.6541 & 0.2859 & 0.4795 & 0.2509 & 0.2227 & 1.0000 & \\
\hline PBIT & 0.3544 & 0.2126 & 0.3645 & 0.1446 & 0.5019 & 0.3611 & 1.0000 \\
\hline
\end{tabular}

\section{Source: Author's summary of correlation computation (2017)}

The use of correlation matrix is to check for multi-colinearity and to explore the association between each explanatory variable and the dependent variable. The table above shows the correlation between equity and debt finance ratio, interest tax, dividend tax, company income tax, tax shield and profit before interest and tax.

The findings from the correlation matrix table, shows that there exist a strong positive association between equity and debt finance ratio (0.5877), this clearly shows that equity and debt finance ratio are both close proxy for capital structure. In the case of interest tax (INTAX- DIVTAX $=-0.0052, \mathrm{CIT}=0.2122, \mathrm{TAS}=0.4795, \mathrm{PBIT}=0.3645$ ) we observed that interest tax was positively and strongly associated with CIT TAS, PBIT but weakly and negatively associated with DIVTAX. Dividend tax (DIVTAX- CIT $=-0.2493$, TAS $=$ 0.2509 , PBIT $=0.1446$ ) it was observed that dividend tax was positively and strongly associated with TAS, and PBIT but negatively associated with CIT. We observed that company income tax (CIT- TAS $=0.2227$, PBIT $=0.5019)$ was positively and strongly associated with TAS and PBIT. We also observed that tax shield is strongly and positively associated with profit before interest and tax. In checking for multi-collinearity, we observed that no two explanatory variables were perfectly correlated. This includes our control variable. This means the absence of multi-colinearity problem in our model. Multi-colinearity between explanatory variable may result to wrong signs or implausible magnitudes in the estimated model coefficients, and the bias of the standard errors of the coefficients.

\subsubsection{Debt Financing Ratio Model}

The debt financing ratio pool OLS and WLS regression result examine how taxation impact on company's choice of using debt stock in financing investment. The results obtained are presented in table 4.4.

\begin{tabular}{|l|l|l|l|}
\hline & Expected Sign & Debt Financing Ratio (OLS) & Debt Financing Ratio (WLS) \\
\hline INTAX & + & $\mathbf{1 0 . 1 2 1}$ & $\mathbf{7 . 9 9 1}$ \\
& & $(5.300)$ & $(2.399)$ \\
\hline
\end{tabular}

www.scirj.org

(C) 2018, Scientific Research Journal

http://dx.doi.org/10.31364/SCIRJ/v6.i8.2018.P0818547 


\begin{tabular}{|l|l|l|l|}
\hline & & {$[0.020]^{* *}$} & {$[0.106]$} \\
\hline DIVTAX & + & $\begin{array}{l}\text { 6.7013 } \\
(3.990) \\
{[0.029]^{* *}}\end{array}$ & $\begin{array}{l}\mathbf{5 . 0 9 1 5} \\
(3.861) \\
{[0.028]^{*}}\end{array}$ \\
\hline CIT & + & $\mathbf{3 . 6 0 8 4}$ & $\mathbf{3 . 9 7 5}$ \\
& & $(3.378)$ & $(4.855)$ \\
& & {$[0.648]$} & {$[0.023]^{*}$} \\
\hline TAS & + & $\mathbf{1 1 . 3 4 8}$ & $\mathbf{1 3 . 2 4 7}$ \\
& $(4.509)$ & $(7.107)$ \\
& & {$[0.057]^{* * *}$} & {$[0.000]^{*}$} \\
\hline PBIT & & $\mathbf{4 . 3 4 4 0}$ & $\mathbf{3 . 9 6 8}$ \\
& $(2.401)$ & $(3.621)$ \\
\hline F. St (P. value) & & {$[0.348]$} & {$[0.037]^{* *}$} \\
\hline
\end{tabular}

Note: 1.Parentheses ( ) are t-statistics which Bracket [ ] are P-Value

2. $\quad * 1 \%, * * 5 \%, * * * 10 \%$ level of significance.

In testing for the cause-effect relationship between the dependent and independent variables in the Debt financing ratio, we reported the OLS and WLS pooled regression results. In estimating the OLS result, we follow the assumption of no heteroscedaticity while in the case of WLS we assume the presence of heteroscedaticity and we adopted a weighted transformation process to obtain a more robust result. In selecting from the two pooled regression result we used the WLS, since the results would be more appealing statistically in the context of difference in our sampled companies.

Following the above, we therefore discuss the pooled WLS result from table 4.3 in table 4.3 we observed that the WLS results. The R.sq. adjusted value (0.68) indicated that all the explanatory variable jointly explain about $68 \%$ of the systematic variations in Debt financing ratio of our sample companies over the ten years period. The adjusted R. sq value clearly shows that taxation (at private and corporate level) can help in better understanding the debt financing choice of companies. The F-statistics (18.44) and its P-value (0.00) shows that the Debt financing ratio WLS regression model is generally significant and well specified at $1 \%$ significance levels.

In addition to the above, the specific finding from each explanatory variable from the WLS regression models is provided as followings:

Interest Tax (INTAX), based on the coefficient 7.9910 and p-value of 0.016, interest tax appears to have a positive influence on our sample quoted companies choice of debt financing but the influence is not statistically significant even at $10 \%$ since the p-value was above the 0.10. The result suggests that the tax on interest (individual level) does not have impact on firm decision to finance invest with debt stock. This follows the finding of Michael and Dennis (2008) which shows that there is a positive but not statistical significant relationship between interest tax and debt financing decision.

Dividend Tax (DIV TAX), based on the coefficient value of 5.092, t-value of 3.86 and p-value of 0.029, appear to have a positive effect on debt financing decision and the influence/effect is statistically significant at 5\%. This means tax on dividend (individual level) significantly affects the firm's capital structure decisions. The ability of firm to shift tax burdens to the individual influence their decision to finance investment by debt. 
Company Income Tax (CIT) - based on the coefficient value of 3.9751, t-value of 4.86 and p-value of 0.022 appears to have a positive effect/influence on sample quoted company choice of debt financing and the influence is statistically significant at 5\% level. This indicates that a firm considering the company income tax burden prefers the use of debt financing which allows them enjoy tax shield.

Tax shield (TAS) - based on the coefficient value of 13.25, t-value of 7.11 and p-value of 0.00 tax shield appears to have positive effect on debt financing choice of the sample firm and the effect/influence is statistically significant at $1 \%$ level. This means that firm used debt financing in other to enjoy the interest tax shield which reduces their tax burden and increase their net operating profit. This follows that of Odesa and Ugbah (2016) but negates that of Michael and Dennis (2008).

\subsection{2: $\quad$ Equity Financing Ratio Model}

The debt financing ratio pool OLS and WLS regression result examine how taxation impact on company's choice of using equity stock in financing investment. The result obtained are presented in table 4.4

\begin{tabular}{|l|l|l|l|}
\hline & Expected signs & Equity Ratio (OLS) & Equity Ratio (WLS) \\
\hline INTAX & + & $\begin{array}{l}\text { (1.294 } \\
(1.300) \\
{[\mathbf{0 . 6 9 9}]}\end{array}$ & $\begin{array}{l}4.115 \\
(2.020) \\
{[\mathbf{0 . 7 5 0}]}\end{array}$ \\
\hline DIVTAX & + & 5.164 & 5.043 \\
& & $(2.793)$ & $(4.257)$ \\
& & {$[\mathbf{0 . 0 3 9}]^{* *}$} & {$[\mathbf{0 . 0 0 2}]^{*}$} \\
\hline CIT & + & 6.912 & 8.119 \\
& & $(7.450)$ & $(3.612)$ \\
{$[\mathbf{0 . 0 1 2}]^{*}$}
\end{tabular}

Note: 1.Parentheses ( ) are t-statistics while Bracket [ ] are P-Value

2. $\quad * 1 \%, \quad * * 5 \%, * * * 10 \%$ level of significance.

In testing for the cause-effect relationship between the dependent and independent variables in the Debt financing ratio, we reported the OLS and WLS pooled regression results. In estimating the OLS result, we follow the assumption of no heteroscedaticity while in the case of WLS we assume the presence of heteroscedaticity and we adopted a weighted transformation process to obtain a more robust result. In selecting from the two pooled regression result we used the WLS, since the results would be more appealing statistically in the context of difference in our sampled companies.

Following the above, we will therefore discuss the pooled WLS results from table 4.4. In the table 4.4, we observed that from the WLS result, the R-squared adjusted value was 0.69 . this indicates that all the independent variable jointly explain about $69 \%$ of the systematic variables in equity financing ratio of our sample companies over the period of ten years (2007-2016). This was similar to the Debt financing ratio model, which was $68 \%$. The above adjusted R.squared value clearly shows that taxation and with the control 
variable can help in better understanding the equity finance choice of companies. The F-statistics (25.67) and its P-value (0.00) show that the equity WLS regression model is generally significant and well specified at $1 \%$ levels.

In addition to the above, the specific finding from each explanatory variable from the WLS pooled regression models are provided as followings:

Interest tax (INTAX), based on the coefficient 4.115, t-value 0.0207 and p-value of 0.7504 appear to have positive influence on firm equity financing choice but the influence is not statistically significant. This means that, though firm consider interest tax in making equity financing decision but it does not influence their decision or proportion of equity financing.

Dividend Tax (DIVTAX), based on the coefficient 5.043, t-value 4.257 and p-value 0.0018 dividend tax appears to have positive influence/effect on firm's equity financing choice and the effect/influence was statistically significant at $1 \%$. This indicates that dividend tax influences the equity financing decision of firms.

Company Income Tax (CIT), based on the coefficient 8.1195, t-value 3.6122 and p-value 0.0116 appears to have positive effect on equity financing choice and the effect is statistically significant at $1 \%$. This reveals that company income tax burden is paramount in making financing choice. As using debt financing reduces the company income tax burden through interest tax shield (but increase risk due to the fixed charges associated).

\section{SUMMARY, CONCLUSION AND RECOMENDATION}

Theoretical considerations about companies' capital structure choices suggest that the total tax benefit of debt financing relative to equity taxation does in fact matter. We have empirically analysed the tax effects of taxes on dynamic capital structure choices using a comprehensive panel of firm-level data from 15 industrial firms in Nigeria. We collected detailed tax rates for the corporate profit tax, dividend tax and taxes on interest income then tax shield and profitability as our control variable. First, we combine data from individual tax return data and corporate tax return for a panel of industrial firms in Nigeria during the fiscal years 2003-2017. Using a dynamic capital structure model we found a strong and positive effect of taxation on companies dynamic capital structure decisions. This finding provides strong support for the static trade-off theory of capital structure. Secondly, our empirical results identify a statistical significant positive effect of the relative tax benefit (interest tax and tax shield) on the companies' equity ratio. The results suggest that differences in the tax levels of the return on equity relative to the tax on the return on debt capital do in fact play a significant role in capital structure decision.

\section{2: $\quad$ Recommendations}

Based on the above summary of findings and conclusion, we proffer the following suggestions and recommendations:

There is need for government to reduce the level of personal capital income tax and company income tax.

Moreover, government should put effort on stimulating the use of other sources of financing to relieve the possible excessive company dependent on loan or debt.

\section{References}

Abbasi, E. and Delghandi, M. (2016). Impact of firm specific factors on capital structure based on trade off theory and pecking order theory. An empirical study of Tehran's stock market companies. Arabian journal of business and management review 6(3), 1-4.

Akman, Gokbulut, Temel Nalin and Gokbulut (2015). Capital structure in an emerging stock market: The case of Turkey. Journal of the faculty of Economics and Administrative sciences, 5(2), 639-660.

Al-Shubiri, F. N. (2011). Capital structure and market power; Evidence from Jordanian banks. Managing global transition, 9(3); 289-310. 
Amidu, M. (2007). Determinants of capital structure of banks in Ghana: An empirical approach. Baltic Journal of Management, 2, 67-79.

Andrew M. (2012). How do taxes affect capital structure? The Wharton School, University of Pennsylvania. Email: acmackin@wharton.upenn.edu.

Anila, C. (2013). Impact of firm specific factors on capital structure decisions.An empirical study of Albanian firms. European Journal of Sustainable Development. 2(4), 135-148

Antoniou,A., Guney ,Y. and Paudyal,K. (2002). Determinants of corporate capital structure: Evidence from European countries. University of Durham, working paper.

An, Zhiyong. (2012). Taxation and Capital Structure: Empirical Evidence from a Quasiexperiment in China." Journal of Corporate Finance, 18, 683-689.

Arsov, S. and Naumoski, A. (2016). Determinants of capital structure: an empirical study of companies from selected post transition economics. Zb. rad. Ekon. fak. Rij. 34(1); 119-146.

Auclert, Adrien and Daan Struyven. (2012). ACE Hit: Does the Corporate Tax Bias Impact Leverage? Working paper, Massachusetts Institute of Technology.

Ayers, B., Cloyd, B. and Robinson, R. (2001). The influence of income taxes on the use of inside and outside debt by small businesses. National tax journal, 54(1), 27-55.

Baral, K. J. (2004): Determinants of capital structure: A case study of listed companies in Nepal. The Journal of Nepalese Business Studies, 1(1):1-13.

Bhaduri, S.N. (2002). Determinants of capital structure choice: a study of the Indian corporate sector. Applied financial economics, 12, 655-665.

Booth, L., Aivazian, V. Demirgüc-Kunt, A. Maksimovic, V. (2001). Capital structure in developing countries. Journal of Finance, 56(1):87-130.

Brealey, R., Myers, S. and Franklin A. (2000). Principles of corporate finance. (10 ${ }^{\text {th }}$. ed) McGraw-Hill/Irwin.

Brigham, E. and Ehrhardt,M.(2008) Financial Management: Theory and Practice. (12 $2^{\text {th }}$ ed.), USA,Thomson Learning.

Buttner, T., Overesch, M., Schreiber, U. and Wamser, G., (2006). Taxation and the choice of capital structure. Evidence from a panel of German multinationals, CESifo Working Paper 1841, Munich.

Campenhout,Van Geert, and Tom Van Caneghem. (2013). How Did the Notional Interest Deduction affect Belgian SMEs' Capital Structure? Small Business Economics, 40, 351-373.

Cheng Deng (2015). Impact of corporate income tax on the capital structure of Canadian listed companies.

Chen, J. Strange, R. (2005). The determinants of capital structure: Evidence from Chinese listed companies. Economic Change and Restructuring, 38(1):11-35.

Chen, Y. Hammes, K. (2004). Capital structure theories and empirical results: A panel data

WwW.scirj.org

(C) 2018, Scientific Research Journal http://dx.doi.org/10.31364/SCIRJ/v6.i8.2018.P0818547 
analysis Available: http://www.ssrn.com/abstract=535782

Daskalakis, N. and Psillaki M. (2006). The determinants of capital structure of the SME's: Evidence from the Greek and the French firms, unpublished.

Degryse,H. , Goeij P. \& Kappert P.(2009). The impact of firm and industry characteristics on small firms' capital structure: Evidence from Dutch panel data. European Banking Center Discussion.

Devereux, M. P., Maffini, G. and Jing Xing (2015). Corporate tax incentive and capital structure: Empirical evidence from UK tax returns.

Doidge, Craig and Alexander Dyck. (2012). Taxes and Corporate Policies: Evidence from the Canadian Income Trust Market. Working Paper, University of Toronto.

Drobetz, W. Pensa, P. Wanzenried, G. (2007). Firm characteristics, economic conditions and capital structure adjustments. Working paper, University of Basel, Basel.

Faccio, Mara, and Jin Xu. (2011). Taxes and Capital Structure. Working Paper, Purdue University.

Fama, E., and French, K. (2002). Testing trade-off and pecking order predictions about dividends and debt, The Review of Financial Studies, 15(1), 1-33

Frank, M.Z. and Goyal, V.K (2005). Trade-off and pecking order theories of debt.

B.Espen Eckbo,Handbook of Corporate Finance, Empirical Corporate Finance.

Gerge Contos (2010). An essay on the effects of taxation on the corporate financial policy. Internal revenue service.

Graham, John R. (1999). Do Personal Taxes Affect Corporate Financing Decisions?Journal of Public Economics, 73,147-185.

Graham, J.R. (2000). How big are the tax benefits of debt? Journal of finance 55, 1901-1941.

Graham, J. R. and Mills, L. F. (2008). Using tax returns data to stimulate corporate marginal tax rates. Journal of Accounting and Economics 46(2-3), 366-388.

Gordon, H., and Young Lee, (2001). Do Taxes Affect Corporate Debt Policy? Evidence from U.S. Corporate Tax Return Data. Journal of Public Economics, 82(2). 195-224.

Hall, G.C., Hutchinson, P. J. and Michaelas, N. (2004). Determinants of the Capital Structures of European smes.' Journal of Business Finance and Accounting 31 (5-6): 711-28.

Hassan, A., Tanveer, M., Siddique, M. and Madasar, M. (2013). Tax shield and its impact on corporate dividend policy: Evidence from Pakistani Stock Market. IBusiness 5, 184-188

Heider, Florian and Alexander Ljungqvist. (2012). As Certain as Debt and Taxes: Estimating the Tax Sensitivity of Leverage from Exogenous State Tax Changes. Working Paper, European Central Bank and New York University.

Hemmelgarn, T. and Teichmann, D. (2013). Tax reforms and the capital structure of Banks. Taxation papers no. 37

Karasahin, R. and Kucuksarac, D. (2016). Revisiting capital structure of nonwww.scirj.org 
financial public firms in Turkey. Working papers no 16/09.

Kestens, Katrien, Philippe Van Cauwenberge, and Johan Christiaens. (2012). An Investigation of the Effect of the Notional Interest Deduction on the Capital Structure of Belgian SMEs." Unpublished Working Paper.

Liu, H., Zhang, Y. and Gao, S. (2015). Dividend tax and capital structure: Evidence from China. China journal of Accounting studies, $3(3)$.

Miglo, A. (2016). Capital structure in the modern world (1 $1^{\text {st }}$.ed.) Palgrave macmillan. Springer International Publishing AG Switzerland.

Mintz, J. and Weichenrieder, A. J. (2005). Taxation and the financial structure of German outbound FDI, CESifo Working paper 1612, Munich

Mishra, C. S. (2011). Determinants of capital structure- A study of manufacturing sector PSUs in India. International conference on financial management and economics

Mirrlees, J., Stuart, A., Jim, B., Richard, B., Stephen, B., Robert, C., Malcolm, G., Paul, J. Gareth, M. and James, P., (2012). The Mirrlees review: A proposal for systematic tax reform. National Tax Journal, 65, 655-683.

Modugu, K. N. (2013). Capital structure decision: An overview. Journal of finance and bank management,1(1), 14-27.

Murinde, V., J. Agung, and A. W. Mullineux. (2004). 'Patterns of Corporate

Financing and Financial System Convergence in Europe.' Review of International Economics 12 (4): 693-705.

Myers, S. C. (2003). Financing of corporations. In G. Constantinides, M. Harris, and R. Stulz (Eds.), Handbook of the Economics of Finance, Volume 1A, Chapter 4, 216-245. Amsterdam: Elsevier.

Narmandakh, B. (2014) Determinants of capital structure: Pecking order theory. Evidence from Mongolian listed firms.

Nwangi, L. W., Makau, M. S. and Kosimbei, G. (2014). Relationship between capital structure and performance of non-financial companies in the Nairobi securities exchange, Kenya. Global Journal of comtemporary research in Accounting, Auditing and business ethics (GJCRA) International research journal. 1(2), 73-91.

Ogbulu O. and Emeni F (2012). Determinants of corporate capital structure in Nigeria. International journal of economics and management sciences 1 (10), 81-96

Ogebe P, Ogebe J. and Alewi K. (2013). The impact of capital structure on firms' performance in Nigeria. Munich Personal Repec Archive 3

Orjinta, H. I and Agubata, N. S. (2017). Effect of taxes on capital structure decisions: Evidence from Non- Financial Firms. Palgo Journal of Business Management 4(1), 95-102

Overesch, M, and Voeller (2010). The impact of personal and corporate taxation on capital Structure choices. FinanzArchiv: Public finance Analysis, 66(3), 263-294.

Pablo Fernandez (2004). The value of tax shields is not equal to the present value of tax shields. Journal of financial economics 73(1); $145-165$ 
Pablo Fernandez (2006). The correct value of tax shields: An analysis of 23 theories. Working papers no 628.

Panier, F. Perez-Gonzalez, F. and Villanueva, P. (2012).Capital structure and taxes; what happens when you (also) subsidize equity.

Pepur, S. Curak, M. and Poposki, K. (2016). Corporate capital structure: The case of large Croatian companies. Online publication available in http://dx.doi.org/10.1080/1331677x.2016, 498-514.

Pratheepan, T. and Banda, Y. K. W. (2016). The determinants of capital structure:

Evidence from selected listed companies in Sri Lanka. International journal of economics and finance; 8(2), 1-13

Princen, Savina. (2012).Taxes of Affect Financing Decisions: The Case of Belgian ACE." CESIFO Working Paper

Sanusi, N. and Taha, R. (2015). An empirical analysis of capital structure decisions in Malaysian listed companies. Journal of sustainability science and management 10(2); 65-73

Schepens Glenn (2015). Taxes and Bank capital structure. European Central Bank.

Sorana, V. (2015). The impact of capital structure on financial performance in Romanian listed companies. International journal of academia. 2(1), 23-34.

Teraoui, H., Chichti, J. and Ecstra, E. (2012). Taxation and capital structure choice: Survey evidence. International journal of management sciences and Business research, 1(4)

Theis, C. (2009). What is the value of the tax shield of debt? Diploma thesis, Diplomarbeit Universitat Trier.

Vasiliou, D. Eriotis, N. Daskalakis, N. (2005). The determinants of capital structure: Evidence from the Greek market. Working paper, University of Piraeus, Piraeus.

Xu, J. (2012). Profitability and Capital Structure: Evidence from Import Penetration.Journal of Financial Economies, 106,427-446.

Zietlow, J. Hankin, J. Seidner, A. (2007). Financial management for non-profit organizations: Policies and practices. Hoboken, NJ: Wileys 